\title{
Studies on dosage-mortality response of diamondback moth, Plutelaxylostella L. larvae to different insecticides in combination with Streptocycline
}

\author{
D. SIDDARTHA*1, REVANNA REVANNAVAR ${ }^{2}$ AND R. SOMU ${ }^{1}$ \\ ${ }^{1}$ College of Horticulture, University of Horticultural Sciences, BAGALKOT (KARNATAKA) INDIA \\ ${ }^{2}$ Department of Entomology, College of Horticulture, MUDIGERE (KARNATAKA) INDIA
}

\begin{tabular}{|c|c|}
\hline ARITCL & INFO \\
\hline Received & : 08.05.2014 \\
\hline Revised & : 01.08 .2014 \\
\hline Accepted & : 16.08 .2014 \\
\hline
\end{tabular}

KEY WORDS :

Diamondback moth, Insecticide, Bactericide, Synergism, Antagonism

*Corresponding author: Email: Sidduhort@gmail.com

\begin{abstract}
The toxicity of insecticides with bactericide and individual insecticides to test insect was quantified by adopting leaf dip bioassay method and the compatibility was assessed based on the median lethal concentrations $\left(\mathrm{LC}_{50}\right)$. The results clearly revealed that in some combinations toxicity was enhanced while in others the toxicity was lowered. Among seven insecticides in combination with bactericide, streptocycline tested for efficacy, four insecticides (chlorantraniliprole, flubendiamide, Proton ${ }^{\circledR}$ and profenophos) showed synergistic effect (SF $1.18,1.07,1.03$ and 1.01, respectively), whereas three insecticides (indoxcarb, novaluron and Hamla $^{\circledR}$ ) were antagonistic (SF 0.83, 0.89 and 0.93 , respectively) against $P$. xylostella larvae.

How to view point the article : Siddartha, D, Revannavar, Revanna and Somu, R. (2014). Studies on dosage-mortality response of diamondback moth, Plutelaxylostella L. larvae to different insecticides and in combination with Streptocycline. Internat. J. Plant Protec., 7(2) : 354-359.
\end{abstract}

